\title{
Performance Evaluation of Top Five Mutual Funds in India-A comparative study
}

\author{
Ch.Venugopal Reddy \\ Faculty in management studies $U C E \& T, M G U$, Nalgonda.
}

\begin{abstract}
Evaluation of performance of mutual funds in India is carried out through relative Performance index, risk-return profile. The data is drawn from day to day NAVs. The source of data is elicited from organizational website www.indianinfoline.com and www.nseindia.moneycontrol.com
\end{abstract}

Keywords: Mutual fund, risk factor, Risk-return investment, security.

\section{Introduction}

Now a day's Mutual Funds has become a most popular and effective way for investors to participate in financial markets in an easy, low-cost instrument, while minimizing risk characteristics by spreading the investment across different types of securities, also known as diversification. It can play a vital role in an individual's investment strategy. They offer the potential for capital growth and income through investment performance, dividends and distributions under the guidance of a portfolio manager who makes investment decisions on behalf of mutual fund unit holders. Over the past decade, mutual funds have increasingly become the investor's vehicle of choice for long-term investment. It becomes essence to study the performance of the mutual fund. The relation between risk-return determines the performance of a mutual fund scheme. As if every coin has two sides likewise risk is commensurate with return, therefore, providing maximum return on the investment made within the acceptable associated risk level helps in bifurcating the better performers from the laggards. Many asset management companies are working in India, so it is necessary to study the performance of it which may be useful for the investors to select the right mutual fund.

A mutual fund is a common pool of money into which investors with common investment objectives place their contributions that are to be invested, in accordance with the stated objective of the scheme. The investment manager invests the money collected into assets that are defined by the stated objective of the scheme. For example, an Equity fund would invest in Equity and Equity related instruments and a Debt fund would invest in Bonds, Debentures, Gilt edged securities etc.

\section{Objectives Of The Study}

1. To know about types of mutual funds in detail.

2. To find the extent of diversification in the portfolio of securities of sponsored mutual funds

3. To study change in investment pattern

4. To evaluate and compare the performance of equity diversified mutual fund schemes of Selected companies

5. To compare the performance of equity diversified mutual fund schemes of selected Companies' vis-à-vis the market

\section{Research Methodology}

The source of data used is Secondary in nature and is considered as a basis of analysis in this research. Top five asset management companies is selected as per AUM as on March 4, 2016.. Five equity diversified mutual fund schemes, debt mutual funds and hybrid funds etc each from selected AMCs is selected randomly. Daily data about the closing Net Asset Value of the selected schemes has collected from the websites www.indiainfoline.com and www.nseindia.moneycontrol.com. The most popular and widely tracked NSE SENSEX is used as a proxy for the market. The reference period for the data is taken from March 2011 to March 2016.

Data Analysis:

a) Equity diversified (Table 1):

\begin{tabular}{|l|l|l|l|l|l|l|l|l|}
\hline Scheme name & Asset (Rs. Cr) & NAV & $1 \mathrm{w} \%$ & $3 \mathrm{w} \%$ & $6 \mathrm{w} \%$ & $1 \mathrm{y} \%$ & $3 \mathrm{y} \%$ & $5 \mathrm{y} \%$ \\
\hline $\begin{array}{l}\text { ICICI Pru Exp\&Other Services- } \\
\text { DP (G) }\end{array}$ & 7.31 & 28.59 & 1.1 & 4.6 & 15.3 & 31.1 & 45.0 & -- \\
\hline $\begin{array}{l}\text { ICICI Pru Exp\&Other Services- } \\
\text { RP (G) }\end{array}$ & 183.34 & 28.39 & 1.1 & 4.6 & 15.1 & 30.6 & 44.2 & 82.5 \\
\hline $\begin{array}{l}\text { ICICI Pru US Bluechip - Direct } \\
(\mathrm{G})\end{array}$ & 11.65 & 15.82 & 0.6 & 1.1 & 4.0 & 15.7 & 42.9 & -- \\
\hline
\end{tabular}


Performance Evaluation of Top Five Mutual Funds in India-A comparative study

\begin{tabular}{|l|l|l|l|l|l|l|l|l|}
\hline $\begin{array}{l}\text { ICICI Pru US Bluechip Equity } \\
(\mathrm{G})\end{array}$ & 180.65 & 15.70 & 0.6 & 1.0 & 3.8 & 15.3 & 42.3 & -- \\
\hline $\begin{array}{l}\text { Birla SL Intl. Equity A -Direct } \\
(\mathrm{G})\end{array}$ & 8.62 & 15.96 & 0.1 & -0.4 & 3.7 & 11.8 & 30.7 & -- \\
\hline
\end{tabular}

\section{Interpretation:}

Table 1 depicts the performance of selected equity diversified schemes return for a period of 2011 to 2016. It also depicts the average Portfolio return and scheme return performance in comparison to the benchmark.The fifth column shows the schemes-wise return for five years in which gives highest return of 82.5\% in the year 2016 by ICICI Pru Exp \& Other Services-RP (G) and also from the inception. It is followed by ICICI Pru Exp \&Other Services-DP (G), ICICI Pru US Bluechip - Direct (G), ICICI Pru US Bluechip Equity (G) and Birla SL Intl. Equity A -Direct (G) with 45.0, 42.9, 42.3, 30.7 return respectively.In all five years duration ICICI Pru Exp \&Other Services-RP $(G)$ is performed well compared to others schemes.

b) Debt Long Term (Table 2):

\begin{tabular}{|l|l|l|l|l|l|l|l|l|}
\hline Scheme name & Asset (Rs. Cr) & NAV & $1 \mathrm{w} \%$ & $3 \mathrm{w} \%$ & $6 \mathrm{w} \%$ & $1 \mathrm{y} \%$ & $3 \mathrm{y} \%$ & $5 \mathrm{y} \%$ \\
\hline L\&T Gilt Fund - Direct (G) & 38.90 & 29.58 & 0.2 & 2.1 & 2.3 & 5.3 & 9.6 & -- \\
\hline ICICI Pru Long Term Plan (G) & 57.26 & 13.80 & 0.2 & 0.7 & 2.6 & 5.3 & 9.6 & 20.4 \\
\hline ICICI Pru Long Term - Direct (G) & 3.04 & 13.80 & 0.2 & 0.7 & 2.6 & 5.3 & 9.6 & -- \\
\hline $\begin{array}{l}\text { Templeton Corporate Bond-Direct } \\
\text { (G) }\end{array}$ & 36.96 & 12.48 & 0.2 & 1.0 & 2.8 & 6.4 & 9.4 & -- \\
\hline ICICI Pru Long Term Plan-PP (G) & 5.02 & 13.63 & 0.1 & 0.7 & 2.5 & 5.2 & 9.3 & 19.8 \\
\hline
\end{tabular}

\section{Interpretation:}

Table 2 depicts the performance of selected Debt Long Term return for a period of 2011 to 2016. It also depicts the average Portfolio return and scheme return performance in comparison to the benchmark.The fifth column shows the schemes-wise return for five years in which gives highest return of $20.4 \%$ in the year 2016 by ICICI Pru Long Term plan (G) and also from the inception followed by ICICI Pru Long Term Plan-PP (G) with return of $19.8 \%$. It is followed by L\&T Gilt Fund - Direct (G), ICICI Pru Long Term - Direct (G) and Templeton Corporate Bond-Direct (G), with 9.6, 9.6 and 9.4\% for third year return respectively. In all five years duration, ICICI Pru Long Term Plan $(\mathrm{G})$ and ICICI Pru Long Term Plan-PP $(\mathrm{G})$ is performed well compared to others schemes.

c) Hybrid: Top 5 funds in India (Table 3):

\begin{tabular}{|l|l|l|l|l|l|l|l|l|}
\hline Scheme name & Asset (Rs. Cr) & NAV & $1 \mathrm{w} \%$ & $3 \mathrm{w} \%$ & $6 \mathrm{w} \%$ & $1 \mathrm{y} \%$ & $3 \mathrm{y} \%$ & $5 \mathrm{y} \%$ \\
\hline FT (I) FF US Opp. -Direct (G) & 47.14 & 17.97 & 1.0 & 2.2 & 7.8 & 21.3 & 55.1 & -- \\
\hline $\begin{array}{l}\text { FT (I) Feeder-Franklin US } \\
\text { Opp.(G) }\end{array}$ & 455.13 & 17.77 & 1.0 & 2.1 & 7.5 & 20.6 & 53.5 & - \\
\hline $\begin{array}{l}\text { DSP BR US Flexible* Equity- } \\
\text { Direct(G) }\end{array}$ & 46.81 & 15.25 & -- & 1.6 & 7.1 & 16.5 & 44.8 & -- \\
\hline $\begin{array}{l}\text { DSP BR US Flexible* Equity } \\
\text { Fund (G) }\end{array}$ & 36.09 & 15.14 & -- & 1.5 & 7.0 & 16.2 & 43.8 & -- \\
\hline $\begin{array}{l}\text { DWS Top Euro land Offshore } \\
\text { Fund (G) }\end{array}$ & 3.96 & 13.18 & -0.4 & 0.9 & 3.1 & 17.1 & 29.3 & 53.4 \\
\hline
\end{tabular}

\section{Interpretation:}

Table 3 depicts the performance of selected Hybrid: Top 5 funds in India for a period of 2011 to 2016. It also depicts the average Portfolio return and scheme return performance in comparison to the benchmark.The fifth column shows the schemes-wise return for five years in which gives highest return of $20.4 \%$ in the year 2016 by DWS Top Euro land Offshore Fund (G). It is followed by FT (I) FF US Opp. -Direct (G), FT (I) FeederFranklin US Opp. (G), DSP BR US Flexible* Eqty-Direct (G) and TDSP BR US Flexible* Equity Fund (G) with 55.1, 53.5, 44.8 and $43.8 \%$ for third year return respectively In all five years duration, DWS Top Euro land Offshore Fund $(\mathrm{G})$ is performed well compared to others schemes.

\section{Over all Interpretation:}

Various types of mutual funds have various levels of volatility or potential price, and those with the higher chance of losing value are also the funds that can yield greater returns for us over time.So risk has two sides: it causes the value of your investments to fluctuate, but it is precisely the reason you can expect to earn higher returns.Conventionally, the difference between debt and equity is the risk involved. Debt is that encompasses bank deposits, government-backed deposits, other deposits as well as mutual funds that invest in debt paper. Equity means stocks as well as equity mutual funds. Everyone knows that debt is less risky than 
equity, and that's true. However, for the purpose of planning a targeted investment, it's more useful to think of debt and equity in a different manner.

The important difference between the two is that their risk and return curve varies in a very different way over different time-scales. Debt returns are predictable and there are many government-guaranteed deposits available to the Indian investor. Risk then, refers to the volatility - the up and down activity in the markets and individual issues that occur constantly over a period of time. This volatility can be caused by a number of factors - interest rate changes, inflation or general economic conditions. It is this variability, uncertainty and potential for loss, that causes investors to worry. We all fear the possibility that a stock we invest in will fall substantially. But it is this very volatility that earns higher long-term returns from these investments, than from a savings account.

\section{Suggestions}

From the above analysis it can be suggested that Debt returns are low, barely matching or only slightly exceeding the rate of inflation. Equity returns have the potential of being much higher but can be volatile. However, the volatility of equity is a relatively short-term phenomenon. For periods exceeding three to five years, equity investments are extremely likely to give strong positive returns. This is especially true if stick to a broad selection of the relatively large-cap companies and if you invest gradually, as in through an SIP. Speaking in terms of risk, this means that instead of saying that equity has higher risk, we should actually be saying that equity's risk drops over time and at a long enough timescale, the returns to- risk ratio becomes far more attractive than debt. And there's the point about how all this fits into your targeted investment goals. The formula is simple - debt for the short-term, and equity for the long-term.

Managing director, Vivek Kudva India and central and Eastern Europe, Middle East and Africa, Franklin Templeton Investments is of the opinion that "There has been a substantial increase in interest for fixed income mutual funds (especially among high net worth individuals) - a reflection of the growing awareness of the category. Over the last year or so, corporate bond funds focused on high coupons had seen increased flows. In recent months, there has been a shift in favor of long bond funds with relatively higher maturities (both gilts and corporate bonds), as investors were looking to take advantage of the expected fall in interest rates. On the equity side, sharp rallies have resulted in profit booking in equity funds while periods of market corrections have seen positive net flows.

\section{Conclusion}

Domestic investors rushed to exit equity funds in January and shifted focus to debt in anticipation of low interest rate regime in the coming quarters. Mutual fund investors pulled out a record Rs.4,713 crore from equity schemes of asset management companies (AMCs), the highest in any January and also the highest monthly redemption of equity schemes in 27 months. While equities saw the highest monthly redemption ever, AMCs' debt schemes attracted Rs.43,804.7 crore - the highest inflow in any January. Overall, all selected mutual fund companies have positive return during 2011 to 2016.. ICICI mutual fund has performed well. Birla SL Intl. Equity A -Direct (G) and DWS Top Euro land Offshore Fund (G) mutual fund have lower level of risk compare to Franklin and DSP. The rise in stock prices encouraged investors to book profits and shift money to debt schemes because the latter will generate healthy returns when interest rates soften, fund managers said. Clearly, investors are not convinced the stock market will continue to rise, with key indices touching a new high this year.

\section{Bibliography}

[1]. Agarwal, D. (2006). Measuring Performance of Indian Mutual Funds. Prabandhan, 179-185.

[2]. Agarwal, D. (2006). Measuring Performance of Indian Mutual Funds. Prabandhan, 179-185.

[3]. Guha, S. (2008). Performance of Indian Equity Mutual Funds vis-a-vis their Style

[4]. Benchmarks. The ICFAI Journal of Applied Finance , 49-812. http://www.indiainfoline .com/ MutualFunds/ Balanced- Funds.aspx

[5]. http://nseindia.moneycontrol.com/mutualfundindia/tracker_home.php

[6]. http://www.indiainfoline.com/MutualFunds/Debt-Funds.aspx

[7]. http://www.indiainfoline.com/MutualFunds/Equity-Funds.aspx

[8]. http://www.dnb.co.in/bfsisectorinindia/MFund5.asp.

\section{Biography}

CH.VenuGopal Reddy: B.Com (Hons.), MBA(Finance), M.Com, currently working as a faculty in university

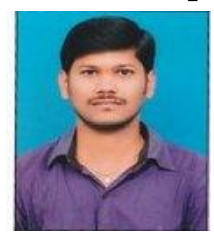
college of Engg. \& Technology, Mahatma Gandhi University, Nalgonda, Telangana, Areas of interest: Accounting and Finance. 